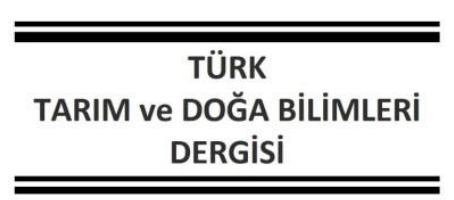

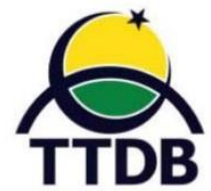

www.dergipark.gov.tr/turkjans Araştırma Makalesi

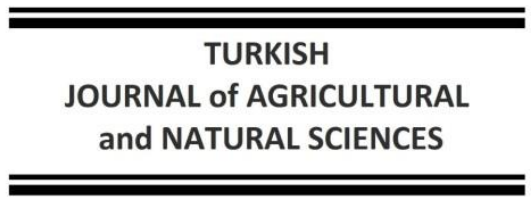

and NATURAL SCIENCES

\title{
Farklı Oranlarda Üre ve Melas Katkılarının Filotu (Miscanthus x giganteus) Silajlarının Fiziksel ve Bazı Kalite Özellikleri Üzerine Etkileri
}

\author{
Kadir BOLAKAR ${ }^{1}$, Osman YÜKSEL ${ }^{2 *}$ \\ ${ }^{1}$ Kozaklı İlçe Tarım ve Orman Müdürlüğü, Kozaklı, Nevşehir \\ ${ }^{2}$ Uşak Üniversitesi, Ziraat Fakültesi, Tarla Bitkileri Bölümü, Uşak \\ *Sorumlu Yazar: osman.yuksel@usak.edu.tr
}

Geliş Tarihi: 09.12.2020 Düzeltme Geliş Tarihi: 09.03.2021 Kabul Tarihi: 08.04.2021

\section{$\overline{O ̈ z}$}

$\mathrm{Bu}$ çalışma salkım çıkarma öncesi dönemde hasat edilerek silolanan filotu (Miscanthus $x$ giganteus) silajlarına farklı oranlarda üre ve melas katkılarının silajların fiziksel ve bazı kalite özelliklerine etkilerini belirlemek amacıyla 2018 yılında Uşak'ta yürütülmüştür. Çalışmada filotu silajlarına \%0.5, 1 ve 1.5 oranında üre ve \%0, 2 ve 4 oranında melas katkıları uygulanarak silajların kuru madde oranı, fiziksel özellikleri, pH, fleig puanı, ham protein oranı, nötr çözücülerde çözünmeyen lif (NDF), asit çözücülerde çözünmeyen lif (ADF) ve nispi yem değerleri (RFV) belirlenmiştir. Araştırmadan elde edilen sonuçlara göre silajların pH değerleri 3.78 ile 6.13 arasında, fleig puanları 35.86 ile 129.71 arasında, ham protein oranları \%5.47 ile \%8.35 arasında, NDF ve ADF oranları sırasıyla \%69.09 ile \%76.81 ve \%42.33 ile \%49.49 arasında değişmiştir. Uygulamalara bağlı olarak RFV değerleri ise 61.28 ile 75.29 arasında değişim göstermiştir. Çalışmada üre katkıları silajların ham protein oranlarını olumlu yönde etkilerken silaj fermantasyonu ve sindirilebilirlik ile ilgili özellikleri olumsuz yönde etkilemiştir. Melas katkıları ise silajların kuru madde ve ham protein oranı dışındaki özelliklerini olumlu etkilemiştir. Araştırma sonucunda yüksek ham protein oranı ve sindirilebilirlik için filotu silajlarına \%1 oranında üre ve $\% 4$ oranında melas ilave edilmesinin gerektiği sonucuna varılmıştır.

Anahtar kelimeler: Filotu, Miscanthus x giganteus, silaj, üre, ham protein

\section{Effects of Different Urea and Molasses Additives on Physical and Some Quality Properties of Elephantgrass (Miscanthus $x$ giganteus) Silages}

\begin{abstract}
The study was carried out in order to determine the effects of urea and molasses additives on physical and some quality properties of giant miscanthus (Miscanthus $\mathrm{x}$ giganteus) silages harvested at the booting stage in Usak in 2018. In the research, 0, 0.5, 1 and 1.5\% urea and 0, 2, 4\% molasses were applied to silages and dry matter ratio, physical properties, $\mathrm{pH}$, fleig score, crude protein ratio, neutral detergent fiber (NDF), acid detergent fiber (ADF), and relative feed values (RFV) of silages were determined. According to the results obtained from the research, $\mathrm{pH}$ values of silages ranged between 3.78 and 6.13 , fleig scores between 35.86 and 129.71, crude protein ratios between 5.47 and $8.35 \%$, NDF and ADF ratios ranged between $69.09 \%$ and $76.81 \%$ and $42.33 \%$ and $49.49 \%$, respectively. Depending on the applications RFV values ranged between 61.28 and 75.29. In the study, urea additives positively affected the crude protein content of silages while negatively affecting the parameters silage fermentation and related to digestibility. On the other hand, molasses additions positively affected the all parameters of silages except dry matter and crude protein content. As a result of the research, it was concluded that $1 \%$ urea and $4 \%$ molasses should be added into silages for high crude protein content and digestibility.
\end{abstract}

Key words: Giant miscanthus, Miscanthus x giganteus, silage, urea, crude protein 
Silo yemi, entansif hayvancılık üretimi yapan ülkelerde et ve süt sığırları başta olmak üzere geviş getiren hayvanların ekonomik, dengeli ve yeterli beslenmelerinde kullanılan önemli bir yem kaynağıdır (Tümer, 2001). Silaj, yeşil aksama sahip bitkilerin hemen hemen hepsinden yapılabilmektedir. Ancak, silajı yapılacak yeşil yemde kuru madde oranı ve kolay çözünebilen karbonhidrat içeriği önemli iki unsurdur (Kaiser et al., 2004). Buğdaygiller familyasındaki bitkilerin neredeyse tamamı silajlık materyalde aranan bu özellikleri karşılayabilmektedirler.

Buğdaygiller familyasına ait bir bitki olan Miscanthus $x$ giganteus, 76 kromozoma sahip tetraploid Miscanthus sacchariflorus ile 36 kromozomlu diploid Miscanthus sinensis'in doğal olarak melezlenmesi sonucu ortaya çıkmış 57 kromozomlu triploid kısır bir melezdir (Greef ve Deuter, 1993). İngilizce adı "Elephantgrass" veya "Giant mischantus" olarak bilinen bu melez ülkemizde "Filotu" veya "Fil çimeni" isimleriyle anılmaktadır. Yetiştirme koşullarına göre 3.5-4 metreye ulaşabilen boyu dolayısıyla filotu hayvan yemi, süs bitkisi, katı-sıvı yakıt kaynağı ve hatta tuğla, sunta gibi yapı malzemelerinin yapımında da kullanılabildiği bilinmektedir (Öztürk, 2008). Fotosentetik olarak bir sıcak iklim buğdaygili olan filotunun tarımı, çok yıllık olması ve rizomlarıla kolayca çoğaltılabilmesinden dolayı mısır ve sorgum gibi tek yıllık bitkilere göre daha ekonomiktir (EI Bassam, 1998). Pek çok buğdaygil türünde olduğu gibi filotunun sap ve yaprakları da karbonhidratlar yönünden oldukça zengin ve kuru madde oranı yüksektir. Bu nedenle bitki kolayca silolanabilmektedir. Lewandowski ve ark. (2000), filotunun Avrupa'nın Akdeniz kıyılarından güney İskandinavya'ya kadar çok geniş bir bölgeye uyum sağlayabildiğini, bitkinin silolanabilmesi için bünyesinde yeterli düzeyde şeker içerdiğini ve silolandıktan iki hafta sonra fermantasyonun tamamlanarak silaj $\mathrm{pH}^{\prime} \operatorname{sın} ı$ 4.2, silaj kuru maddesinin ise $\% 40$ dolaylarında olduğunu bildirmişlerdir. Filotunun verim özellikleri ile silolanabilirliği üzerine İzmir'de yürütülen bir çalışmada bitkinin ham protein oranı \%5.62 olarak belirlenmiştir. Bununla birlikte filotunun dokularındaki yüksek karbonhidratlar nedeniyle herhangi bir katkı maddesi kullanılmaksızın başarıyla silolanabildiği, elde edilen silajlarda $\mathrm{pH}$ değerlerinin ise 3.58 ile 3.79 arasında değişim gösterdiği bildirilmiştir (Geren ve ark., 2011). Yüksel (2019)'in yürüttüğü çalışmada, filotu silajlarının kuru madde oranlarının \%36.69 ile 47.62, pH değerlerinin 4.71 ile 5.09, fleig puanlarının 74.91 ile 111.58, ham protein oranlarının \%4.07 ile 5.20, NDF değerlerinin \%71.46 ile 77.06 ve ADF oranlarının \%49.66 ile \%52.02 arasında değiştiğini bildirilmiştir.
Filotu ile yapılan çalışmalarda genellikle bitkinin kolay silolanabildiği belirtilirken, ham protein oranı ve sinidirilebilirlik özelliklerinin düşük oluşuna vurgu yapılmaktadır. Filotu dışındaki diğer bitkilerde de silaj kalitesini arttırmak için baklagillerle birlikte silolama veya çeşitli silaj katkı maddelerine başvurulmaktadır (Balabanlı ve ark. 2010; Rong ve ark. 2013; Turan ve Seydoşoğlu, 2020). Yapılan çalışmalarda silajların ham protein oranlarını artırmak için genellikle üre katkılarına başvurulduğu, melas ilavelerinin ise silajların fermantasyon özellikleri ile kalitelerini olumlu yönde etkiledikleri bildirilmektedir (Demirel ve Yıldız, 2001; Keskin ve ark. 2005; Güney ve ark. 2007; Kang ve ark. 2018).

$\mathrm{Bu}$ çalışma, salkım çıkarma dönemde biçilerek silolanan filotu silajlarına farklı oranlarda üre ve melas katkısı uygulanarak başta ham protein oranı ve sindirilebilme özellikleri olmak üzere bitkinin silaj kalitesinin artırılması olanaklarının belirlenmesi amacıyla yürütülmüştür.

\section{Materyal ve Metot}

$\mathrm{Bu}$ çalışma, filotu (Miscanthus $x$ giganteus) silajlarına farklı oranlarda üre ve melas ilavesinin silajların fiziksel ve bazı kalite özellikleri üzerine etkilerini belirlemek amacıyla 2018 yılında Uşak'ta yürütülmüştür. Araştırmada, filotu silajlarına $\% 0$, $\% 0.5, \% 1$ ve $\% 1.5$ oranlarında üre ve $\% 0, \% 2$ ve $\% 4$ oranlarında melas katkıları uygulanmıştır. Silajların hazırlanması sırasında kullanılan katkı maddelerinden üre IGSAŞ'tan temin edilen granül formda ve \%46 oranında azot içermekte iken melas, Uşak Şeker Fabrikasından temin edilmiştir. Denemede 4 farklı üre seviyesi, 3 farklı melas dozu ve 3 tekerrür olmak üzere toplam 36 silaj örneği yer almıştır.

Çalışmada, filotu bitkileri salkım çıkarma öncesi dönemde iken el ile hasat edilerek laboratuvara getirilmiştir. Laboratuvarda bitki parçalama blenderinde parçalanmış olan materyale toplam yaş ağırlıkları üzerinden belirlenen oranlardaki üre ve melas ilaveleri yapılarak 1 It hacmindeki plastik kavanozlara doldurulup sıkıştırılmış ve mümkün olduğunca havasız kalmaları sağlanmıştır. Silolanan kavanozlar hava almamaları için ağızları sıkıca kapatıldıktan sonra streç film ile sarılarak fermantasyona bırakılmışlardır (Siesfers ve Bolsen, 1997). 90 günlük bir fermantasyon süresi sonunda silo kavanozları açılarak, kapak kısmına yakın olan yaklaşık 4-5 cm kısımdaki silajlar atılmış, kalan kısım üzerinden silajların renk, koku ve strüktür gibi fiziksel özellikleri DLG (1987), tarafından belirtilen skalaya göre silaj konusunda deneyimli dört farklı kişi tarafından belirlenmiştir. Silaj kavanozlarından alınan yaş silaj örnekleri hassas terazi ile tartıldıktan sonra $105^{\circ} \mathrm{C}^{\prime}$ a ayarlı 
etüvde sabit ağırlığa ulaşana kadar tutulmuş ve yaş ağırlıklarına oranlanarak silajların kuru madde oranları belirlenmiştir. Her bir silaj örneğine ait pH değerleri Akyıldız (1986)'ın belirttiği esaslara göre laboratuvar tipi dijital $\mathrm{pH}$ metre ile belirlenmiştir. Silajların fleig skorları Kılıç (1986)'ın bildirmiş olduğu eşitlikten yola çıkılarak hesaplanmıştır [Fleig Puanı= $220+(2 \times$ \%kuru madde - 15) $-40 \times$ pH)]. Kimyasal analizler için her bir silaja ait öğütülmüş numuneler üzerinden Kjeldahl yöntemine göre (Kacar ve İnal, 2008) azot analizi yapılarak elde edilen azot değerleri 6.25 katsayısı ile çarpılarak örneklerin ham protein oranları belirlenmiştir. NDF ve ADF oranları ANKOM teknoloji tarafından bildirilen yönteme göre tespit edilmiştir (Anonim, 2010). Silajların RFV değerleri Horrocs ve Vallentine, (1999)'in bildirdiği eşitliğe göre hesaplanmıştır [RFV= \%DDM x \%DMI x 0.775 ].

Çalışmadan elde edilen veriler JMP 10.0.0 istatistik paket programında "Tesadüf Parselleri Deneme Desenine" uygun olarak varyans analizine tabi tutulmuşlardır. Varyans analizleri sonucunda istatistik açıdan önemli olduğu ortaya çıkan ortalamaların karşılaştırılmasında asgari önemli fark
(LSD) 0.05 testinden yararlanılmıştır.

\section{Bulgular ve Tartışma}

Farklı oranlarda üre ve melas ilave edilerek silolanan filotu silajlarının fiziksel özellikleri ve kalite sınıflarına ilişkin değerler Çizelge 1 'de gösterilmiştir. Çalışmada belirlenen kalite sınıflarına göre tüm silaj grupları memnuniyet verici ve pekiyi kalitedeki silajlar grubuna dahil olmuşlardır. Genel olarak silajda artan üre katkısı renk puanlarında bir artışa neden olmuştur. Buna karşın üre ilavesi koku değerlerinin azalmasına neden olmuştur. Toplam fiziksel kalite puanında koku değerlerinin etkisi renk ve strüktüre göre daha belirleyici olduğundan artan üre ilavesi toplam kalite puanı azaltmıştır. Buradan hareketle artan üre ilavesi ile silajlarda fermantasyonun olumsuz etkilendiği söylenebilir. Nitekim bazı araştırıcılar (Alçiçek ve Özkan, 1997; Bakıcı ve Demirel, 2004), silaj fermantasyon kalitesi ile silajların fiziksel kalite puanları arasında pozitif bir ilişkinin bulunduğunu bildirmişlerdir.

Çizelge 1. Filotu silajlarının fiziksel özellikleri ve kalite sınıfları*

\begin{tabular}{|c|c|c|c|c|c|}
\hline Silaj grubu & Renk & Koku & Strüktür & Toplam & Kalite Sınıfı \\
\hline Kontrol & 1.00 & 10.33 & 3.50 & 14.83 & Memnuniyet verici \\
\hline$\% 0 \ddot{U}+\% 2 M$ & 1.00 & 11.25 & 3.58 & 15.83 & Pekiyi \\
\hline$\% 0 \ddot{U}+\% 4 M$ & 1.00 & 11.58 & 3.83 & 16.42 & Pekiyi \\
\hline$\% 0.5 \ddot{U}+\% 0 \mathrm{M}$ & 1.83 & 10.17 & 3.50 & 15.50 & Pekiyi \\
\hline$\% 0.5 \ddot{U}+\% 2 M$ & 1.58 & 10.83 & 3.25 & 15.67 & Pekiyi \\
\hline$\% 0.5 \ddot{U}+\% 4 \mathrm{M}$ & 1.58 & 10.08 & 3.42 & 15.08 & Memnuniyet verici \\
\hline$\% 1 \ddot{U}+\% 0 M$ & 1.75 & 10.83 & 3.50 & 16.08 & Pekiyi \\
\hline$\% 1 \ddot{U}+\% 2 M$ & 1.83 & 9.83 & 3.67 & 15.33 & Memnuniyet verici \\
\hline$\% 1 \ddot{U}+\% 4 M$ & 1.92 & 9.08 & 3.33 & 14.33 & Memnuniyet verici \\
\hline \% $1.5 \ddot{U}+\% 0 M$ & 1.83 & 8.08 & 3.53 & 13.44 & Memnuniyet verici \\
\hline \% $1.5 \ddot{U}+\% 2 \mathrm{M}$ & 2.00 & 9.58 & 3.67 & 15.25 & Memnuniyet verici \\
\hline$\% 1.5 \ddot{U}+\% 4 \mathrm{M}$ & 1.75 & 8.83 & 3.50 & 14.08 & Memnuniyet verici \\
\hline
\end{tabular}

*: 16-20: Pekiyi, 10-15: Memnuniyet verici, 5-9: Orta, 0-4: Kötü

Diğer taraftan silajlara melas ilavesi renk puanlarında azalmaya neden olurken koku puanlarının yükselmesine olanak sağlamıştır. Ürenin aksine silajlarda melas ilavesi silaj fermantasyonunu pozitif yönde etkilediği söylenebilir. Toplam puanlara bakıldığında ürenin \%1.5 oranında ilave edildiği silajlar, kontrol ve \%0.5 üre + \%4 melas ilavesinden oluşan gruplar kalite sınıfı olarak diğer silajların gerisinde kalmışlardır. Fiziksel kalite puanlarını Güney ve ark. (2007), üre ve melas ilavesi yaptıkları sorgum silajlarında 13 ile 20 arasında, Yüksel (2019) ise filotu silajlarında 18.33 ile 19.00 arasında değişim gösterdiğini bildirmişlerdir. Bu çalışmada belirlenen değerler Yüksel (2019)'in bildirdiği değerlerden daha düşük bulunurken, Güney ve ark. (2007)'nın bildirdiği değerlerle uyum göstermiştir. Ortaya çıkan bu farklılıklar silajlara uygulanan katkı materyallerinden kaynaklanabileceği gibi silajı yapılan bitkilerin besin maddesi içerikleri ve biçim dönemlerinden de kaynaklanmış olabilir.

Filotu silajlarının kuru madde oranları üre katkıları bakımından \%38.00 ile \%38.18 arasında, melas katkıları bakımından \%38.06 ile \%38.24 arasında çalışmanın genelinde ise \%37.76 ile \%38.44 arasında değişiklik göstermiştir (Çizelge 2). Kuru madde oranları arasındaki bu varyasyon istatistik açıdan bir anlam kazanmamıştır. Yüksel (2019), filotu silajlarında kuru madde oranlarının bitkinin gelişme dönemlerine göre \%36.69 ile \%47.62 arasında değişim gösterdiğini, Lewandowski ve ark. 
(2000) ise filotu silajlarında kuru madde oranının $\% 40$ olduğunu bildirmişlerdir.

Çizelge 2'de silajların $\mathrm{pH}$ değerlerine ait ortalamalar sunulmuştur. Buna göre çalışmada silajlara uygulanan üre ilavesi silaj $\mathrm{pH}^{\prime}$ sının yükselmesine neden olmuştur. Üre uygulaması bakımından silajların $\mathrm{pH}$ değerleri 4.15 ile 5.93 arasında değişmiş, en düşük $\mathrm{pH}$ değeri üre uygulanmayan kontrol grubunda belirlenirken en yüksek pH değeri 5.93 olarak \%1.5 oranda üre uygulanan silajlarda belirlenmiştir.

Silaj $\mathrm{pH}^{\prime} \mathrm{sI}$ silaj kalitesini belirlemede kullanılan önemli bir parametredir. Silajda pH'nın düşmesinin en önemli sebebi silolanma sırasındaki laktik asit üretiminden kaynaklanmakta olup, diğer asitlerin silaj $\mathrm{pH}$ 'sı üzerine etkisi daha azdır (Şakalar ve Kamalak, 2016). Silaj $\mathrm{pH}^{\prime}$ sı üzerine silolanan materyalin kuru madde içeriği yanında ham protein oranı da etkili olabilmektedir. Silajlık üründeki yüksek ham protein veya azotlu bileşikler silajda pH'nın düşmesini engelleyerek tampon etkisi göstermektedirler (Açıkgöz, 2001). Bu açıdan çalışmada artan üre ilavesi silajların pH azalışlarını engelleyerek fermantasyonu olumsuz etkilemiş olabilir. Üre ilavesinin silaj $\mathrm{pH}^{\prime}$ sını artırdığı pek çok araştırıcı tarafından vurgulanmıştır (Filya ve ark., 2004; Çelik ve ark., 2009; Canbolat ve ark., 2014; Kang ve ark., 2018). Diğer taraftan buğdaygil silajlarına baklagillerin ilave edilmesi de $\mathrm{pH}$ üzerinde benzer etkilere neden olmaktadır (Kızılşimşek ve ark., 2020; Turan ve Seydoşoğlu, 2020). Melas katkısı yönünden silajların pH değerleri 5.51 ile 4.81 arasında değişmiştir. En yüksek silaj $\mathrm{pH}^{\prime} \mathrm{sı}$ kontrol grubu silajlarda belirlenirken en düşük $\mathrm{pH}$ değeri 4.81 ile \%4 oranda melas ilavesi yapılan silaj gruplarında belirlenmiştir. Çalışmada genel olarak artan melas ilavesi silaj pH'larının düşmesine olanak sağlamıştır. Kang ve ark. (2018), kasava bitkisinin toprak üstü aksamları ile yaptıkları silajlarda melas katkısının silaj pH'sını 4.5'ten 3.9'a düştürdüğünü, Keskin ve ark. (2005) ise sorgum silajlarında artan melas dozunun silaj $\mathrm{pH}^{\prime}$ sını düşürdüğünü bildirmişlerdir. Melas $\mathrm{pH}$ ilişkisi bakımından araştırıcıların bildirdikleri sonuçlar bu çalışmada belirlenen sonuçlarla uyum göstermektedir. Filotu ile yapılan silajlarının pH değerlerini Geren ve ark. (2011), 3.69 ile 3.78 arasında, Yüksel (2019) ise 4.71 ile 5.09 arasında olduğunu bildirilmişlerdir. Bu çalışmada belirlenen $\mathrm{pH}$ değerleri de araştırıcıların bildirdikleri değerlerle benzerlik göstermektedir.

Filotu silajlarının fleig puanlarına ait ortalama değerler Çizelge 2'de görülebilmektedir. DLG (1987), tarafından bildirilen silaj kalite sınıflarına göre üre uygulanmayan kontrol grubu silajları ile birlikte $\% 0.5$ oranında üre ilavesi yapılarak elde edilen silajların kalite sınıfları pekiyi silajlar grubuna dahil olmuşlardır. Buna karşın ürenin $\% 1$ ve $\% 1.5$ oranda ilave edildiği silaj grupları ise memnuniyet verici silajlar grubuna girmişlerdir. Üre ilavesi yapılan silajların fleig puanları 44.06 ile 115.21 arasında değişmiş, en yüksek fleig puanları kontrolde, en düşük fleig puanları ise \%1.5 oranında üre ilavesi yapılan silajlarda belirlenmiştir. Genel olarak çalışmada artan üre ilavesi silajların fleig puanlarının azalmasına neden olmuştur.

Fleig puanı esas olarak silajın kuru madde oranı ve $\mathrm{pH}$ değerleri üzerinden bir eşitlik ile hesaplanmaktadır. Bu eşitlikte $\mathrm{pH}$ negatif bir etkiye sahiptir. Dolayısıyla silajdaki yüksek pH fleig puanını düşürmektedir. Çalışmada artan dozlardaki üre katkısı silajların $\mathrm{pH}$ değerlerinin yükselterek fleig puanlarının azalmasına neden olmuştur. Fleig puanları melas katkıları yönünden ele alındığında doğrusal bir eğilim ortaya çıkmıştır. Melas ilavesindeki artış fleig puanlarının da yükselmesini sağlamış ve değerler 60.65 ile 89.28 arasında değişmiştir. En yüksek fleig puanı \%4 oranda melas ilavesi yapılan gruplarda gözlenirken, en düşük fleig puanı kontrol grubu silajlarda tespit edilmiştir.

Güney ve ark. (2007), sorgum silajları üzerinde yaptıkları çalışmada silaj kalite grupları açısından bir farklılık olmamakla birlikte silajlarda artan melas ilavesinin fleig puanlarını yükselttiği buna karşın artan üre ilavesinin fleig puanlarında azalmalara neden olduğunu bildirmişlerdir. Diğer taraftan Şakalar ve Kamalak (2016), farklı oranlarda melaslı kuru şeker pancarı posası (MKŞPP) ilavesi yapılarak elde edilen yonca silajında fleig puanlarının da artan MKŞPP ile arttığını bildirmişlerdir. Yüksel (2019), filotu silajlarında fleig puanlarının 74.91 ile 111.58 arasında değiştiğini bildirmiştir. Sonuçlarımız araştırıcıların bildirdikleri değerlerle benzerlik gösterirken Yüksel (2019)'in bildirdiği değerlerden daha düşük bulunmuştur.

Ham protein oranları üre uygulamalarına göre \%5.89 ile \%8.30 arasında değişiklik gösterirken en yüksek ham protein oranı \%1.5 ve \%1 oranda üre katılan silajlarda gözlenmiştir. En düşük ham protein oranı ise \%5.89 ile üre uygulanmayan kontrol grubu silajlarda belirlenmiştir. Üre ilavesi ile birlikte silajların ham protein oranlarının da yükseldiği tespit edilmiştir. Yüksel (2019), yaptığı çalışmada filotu silajlarının ham protein oranlarının \%4.07 ile \%5.20 arasında değiştiğini, düşük seviyelerde olan ham protein oranlarının üre gibi katkı maddeleri ile iyileştirilebileceğini bildirmiştir. Keskin ve ark. (2005), sorgum silajlarına üre ilavesi yaparak elde ettikleri silajlarda ham protein oranlarının \%8.6'dan \%13.80'e yükseldiğini, Nursoy ve ark. (2002), Gözde80 sorgum çeşidi silajlarına $\% 0.5$ oranda üre ilavesi ile ham protein oranının \%7.87'den \%13.17'ye yükseldiğini, Nursoy ve ark. (2003), Arifiye mısır çeşidinde $\% 0.5$ üre ilavesi sayesinde ham protein içeriğinin \%9.22'den \%14.81'e yükseldiği 
bildirilmiştir. Diğer taraftan Canbolat ve ark. (2014), nar posası silajlarında artan üre katkısı ile silaj ham protein oranlarının da arttığını en yüksek ham protein oranlarının $\% 2$ oranda üre ilavesi yapılan silajlarda belirlendiğini bildirmişlerdir. Çeşitli bitkilerin silajlarına üre ilavesinin silajların ham protein oranlarını artırdığına yönelik başka çalışmalar da mevcuttur (Aguilera ve ark., 1997; Güney ve ark., 2007; Kang ve ark., 2018).

Çizelge 2. Farklı oranlarda üre ve melas katkısı yapılan filotu silajlarının bazı özelliklerine ait ortalama değerler

\begin{tabular}{|c|c|c|c|c|c|c|c|c|}
\hline \multicolumn{2}{|c|}{ Üre } & KMO (\%) & $\mathrm{pH}$ & Fleig Puanı & HPO (\%) & NDF (\%) & ADF (\%) & RFV \\
\hline \multicolumn{2}{|c|}{0} & 38.13 & $4.15 \mathrm{D}^{\mathrm{x}}$ & $115.21 \mathrm{~A}$ & $5.89 \mathrm{C}$ & $72.17 \mathrm{C}$ & $45.19 \mathrm{D}$ & $69.45 \mathrm{~A}$ \\
\hline \multicolumn{2}{|c|}{0.5} & 38.17 & $4.89 \mathrm{C}$ & $85.66 \mathrm{~B}$ & 7.26 B & 74.13 B & $47.50 \mathrm{C}$ & 65.14 B \\
\hline \multicolumn{2}{|c|}{1} & 38.00 & $5.34 \mathrm{~B}$ & $67.36 \mathrm{C}$ & $8.22 \mathrm{~A}$ & 75.96 A & 48.61 B & $62.50 \mathrm{C}$ \\
\hline \multicolumn{2}{|c|}{1.5} & 38.18 & $5.93 \mathrm{~A}$ & $44.06 \mathrm{D}$ & $8.30 \mathrm{~A}$ & $75.95 \mathrm{~A}$ & $49.18 \mathrm{~A}$ & $61.95 \mathrm{C}$ \\
\hline \multicolumn{2}{|c|}{$\mathrm{LSD}_{0.05}$} & öd & $0.23^{* *}$ & $9.73^{* *}$ & $0.33^{* *}$ & $0.70^{* *}$ & $0.53^{* *}$ & $0.74^{* *}$ \\
\hline \multicolumn{9}{|c|}{ Melas } \\
\hline \multicolumn{2}{|c|}{0} & 38.06 & $5.51 \mathrm{~A}$ & $60.65 \mathrm{~B}$ & 7.33 & $75.94 \mathrm{~A}$ & $49.11 \mathrm{~A}$ & $62.03 \mathrm{C}$ \\
\hline \multicolumn{2}{|c|}{2} & 38.06 & $4.92 \mathrm{~B}$ & $84.29 \mathrm{~A}$ & 7.43 & 74.74 B & 47.41 B & $64.79 \mathrm{~B}$ \\
\hline \multicolumn{2}{|c|}{4} & 38.24 & $4.81 \mathrm{~B}$ & $89.28 \mathrm{~A}$ & 7.49 & $72.98 \mathrm{C}$ & $46.33 \mathrm{C}$ & $64.46 \mathrm{~A}$ \\
\hline \multicolumn{2}{|c|}{$\mathrm{LSD}_{0.05}$} & öd & $0.20^{* *}$ & $8.42^{* *}$ & öd & $0.60^{* *}$ & $0.49^{* *}$ & $0.64^{* *}$ \\
\hline \multicolumn{9}{|c|}{$\mathrm{U} \times \mathrm{M}$} \\
\hline \multirow{3}{*}{0} & 0 & 37.99 & 4.83 & 87.77 & 5.47 & $76.46 a b$ & $49.18 \mathrm{a}$ & $61.53 \mathrm{gh}$ \\
\hline & 2 & 38.37 & 3.84 & 128.14 & 6.15 & $70.96 \mathrm{e}$ & $44.05 \mathrm{e}$ & $71.54 \mathrm{~b}$ \\
\hline & 4 & 38.02 & 3.78 & 129.71 & 6.07 & $69.09 \mathrm{f}$ & $42.33 \mathrm{f}$ & $75.29 \mathrm{a}$ \\
\hline \multirow{3}{*}{0.5} & 0 & 38.29 & 5.20 & 73.72 & 7.26 & $74.77 \mathrm{c}$ & $48.94 a b$ & $63.16 \mathrm{ef}$ \\
\hline & 2 & 38.05 & 4.70 & 92.97 & 7.11 & $74.78 \mathrm{c}$ & $47.49 \mathrm{c}$ & $64.55 d$ \\
\hline & 4 & 38.17 & 4.78 & 90.28 & 7.41 & $72.84 \mathrm{~d}$ & $46.06 \mathrm{~d}$ & $67.70 \mathrm{c}$ \\
\hline \multirow{3}{*}{1} & 0 & 37.92 & 5.89 & 45.25 & 8.24 & $76.42 \mathrm{ab}$ & $49.12 \mathrm{a}$ & $61.63 \mathrm{gh}$ \\
\hline & 2 & 37.76 & 5.25 & 70.39 & 8.20 & 76.81 a & $48.60 a b$ & $61.80 \mathrm{gh}$ \\
\hline & 4 & 38.33 & 4.88 & 86.45 & 8.21 & $74.65 \mathrm{c}$ & $48.10 \mathrm{bc}$ & $64.08 \mathrm{de}$ \\
\hline \multirow{3}{*}{1.5} & 0 & 38.03 & 6.13 & 35.86 & 8.35 & 76.10 b & 49.21 a & $61.79 \mathrm{gh}$ \\
\hline & 2 & 38.06 & 5.89 & 45.65 & 8.27 & $76.41 a b$ & $49.49 a$ & $61.28 \mathrm{~h}$ \\
\hline & 4 & 38.44 & 5.78 & 50.69 & 8.29 & 75.34 bc & $48.84 a b$ & $62.78 \mathrm{fg}$ \\
\hline \multicolumn{2}{|c|}{$\mathrm{LSD}_{0.05}$} & öd & öd & öd & öd & $1.21^{* *}$ & $0.93^{* *}$ & $1.28^{* *}$ \\
\hline \multicolumn{2}{|c|}{ VK (\%) } & 2.02 & 4.72 & 12.80 & 4.52 & 1.00 & 1.15 & 1.17 \\
\hline
\end{tabular}

**: P $\leq 0.01$ seviyede önemli, öd: Önemli değil, ${ }^{x}$ : Aynı sütunda benzer harf ile gösterilen ortalamalar arasındaki farklar $P \leq 0.05$ seviyede önemsizdir.

Çalışmada melas ilavesinin ve üre $\mathrm{x}$ melas interaksiyonun silajların ham protein oranları üzerine istatistik açıdan önemli bir etkisi olmamıştır. Melas uygulamalarına göre ham protein oranları \%7.43 ile \%7.49 arasında değişiklik göstermiştir. Silajlara melas katkısı üzerine yapılan çalışmalarda melas ilavesinin ham protein oranı üzerine önemli bir etkisinin olmadığı pek çok araştırıcı tarafından da belirtilmiştir (Aguilera ve ark., 1997; Nursoy ve ark., 2003; Güney ve ark., 2007; Kang ve ark., 2018).

Filotu silajlarının NDF oranları üre uygulamalarına bağlı olarak \%72.17 ile \%75.96 arasında değişiklik göstermiştir. En yüksek NDF oranı \%1 ve \%1.5 oranında üre uygulanan silajlardan elde edilirken en düşük NDF oranları üre uygulanmayan kontrol grubu uygulamalarından elde edilmiştir. Genel olarak uygulanan üre oranındaki artışa paralel olarak silajların NDF değerleri de yükselmiştir. NDF oranları melas uygulamalarına göre değerlendirildiğinde oranların \%72.98 ile \%75.94 arasında değiştiği izlenebilmektedir. En yüksek NDF değeri melas uygulanmayan silajlarda belirlenirken en düşük NDF oranı \%4 oranında melas uygulanan silajlardan elde edilmiştir. Melas ilavesindeki artış ürenin aksine silajların NDF oranlarının düşmesine olanak sağlayarak sindirilebilirliğe olumlu katkı sağlamıştır. Üre $\mathrm{x}$ melas interaksiyonunda ise silajların NDF oranları \%69.09 ile \%76.81 arasında değişim göstermiştir. En yüksek NDF oranları sırasıyla \%1 üre + \%2 melas, kontrol, $\% 1$ üre $+\% 0$ melas ve $\% 1.5$ üre + \%2 melas uygulanan silajlarda belirlenmiştir. En düşük NDF oranı ise $\% 0$ üre $+\% 4$ melas uygulanan silajlarda belirlenmiştir.

Nursoy ve ark. (2003), mısır silajlarına üre ve üre+melas uygulamalarından elde ettikleri silajların NDF değerlerinin üre uygulamasından etkilenmediği 
buna karşın üre + melas uygulamalarının NDF oranlarında azalmalara neden olduğunu bildirmişlerdir. Santos ve ark. (2018), sorgum silajlarına uyguladıkları artan üre katkısı ile birlikte silajların NDF oranlarında azalışların ortaya çıktığını, Filya ve ark. (2004), mısır silajlarında artan üre ilavesinin NDF oranlarında azalışlara neden olduğunu, Kang ve ark. (2018) ise kasava silajlarında hem üre ilavesinin hem de melas ilavesinin silajların NDF oranlarını azalttığını ancak melas ilavesinin üre katkısına göre NDF oranındaki azalmada daha etkili olduğunu bildirmişlerdir. Mahala ve Khalifa (2007), sorgum silajlarında artan melas dozları ile birlikte NDF oranlarının önemli ölçüde azaldığını ifade etmişlerdir. Genel olarak önceki çalışmalarda üre katkılarının silajların NDF oranlarını etkilemediği veya azalttığı vurgulanmıştır. Bu çalışmada ise artan üre ilavesi NDF oranlarını yükseltmiştir. Bu durum belki de üre ilavesinden olumsuz etkilenen silaj fermantasyonundan kaynaklanmış olabilir. Melas ilaveleri ise önceki çalışmalara benzer şekilde bu çalışmada da NDF oranlarının azalmasına olanak sağlamıştır.

Çalışmada ADF oranları üre katkıları bakımından \%45.19 ile \%49.18 arasında, melas katkıları bakımından ise \%49.11 ile \%46.33 arasında farklılık arz etmiştir. Üre yönünden en yüksek ADF oranı \%1.5 üre ilave edilen silajlarda, en düşük ADF oranları ise kontrol grubu silajlarda, melas katkısı bakımından ise en yüksek ADF oranı kontrolde en düşük değer ise \%4 melas ilavesi yapılan silajlarda tespit edilmiştir. Araştırmada artan üre katkısı ADF oranlarını yükseltirken bunun aksine melas katkısı ADF oranlarının düşmesini sağlamıştır. Üre $x$ melas interaksiyonunda ise ADF oranları \%49.21 ile \%42.33 arasında değişim göstermiştir.

Filya ve ark. (2004), mısır silajında üre ilavesinin ADF oranlarını azalttığını, en düşük değerlerin \%1 ve \%1.5 üre katkılarından elde edildiğini bildirmişlerdir. Silajlara üre ilavesinin ADF oranlarını düşürdüğüne dair başkaca çalışmalar da mevcuttur (Nursoy ve ark., 2003; Canbolat ve ark., 2014; Kang ve ark., 2018). Santos ve ark. (2018), sorgum silajlarında üre ilavesinin ADF üzerine bir etkisinin olmadığını, Rong ve ark. (2013) ise Pennisetum purpureum'da üre uygulamasıyla ADF oranının kontrole göre yükseldiğini buna karşın melas uygulaması ile azaldığını bildirmişlerdir. Melas katkılarının silajlarda ADF oranlarını azalttığına yönelik çok sayıda araştırma mevcuttur (Aguilera ve ark., 1997; Mahala ve Khalifa, 2007; Bingöl ve ark., 2009; Konca ve ark., 2015). Bu çalışmada belirlenen ADF oranları melas ilavesi bakımından önceki çalışmalarla uyum gösterirken, üre ilavesi bakımından bazı araştırıcıların sonuçlarından ayrışmaktadır. Bu durum NDF oranları kısmında belirtildiği gibi ürenin silaj fermantasyonu olumsuz etkilemesinden kaynaklanmış olabilir.

Filotu silajlarının RFV değerleri 61.95 ile 69.45 arasında değişirken, en yüksek RFV değeri kontrolde en düşük RFV değerleri ise sırasıyla \%1 ve \%1.5 oranda üre katkısı yapılan silajlarda belirlenmiştir. Melas katkıları bakımından RFV değerleri 62.03 ile 64.46 arasında farklılık arz etmiştir. Melas katkıları silajların RFV değerlerini olumlu yönde etkilemiş ve en yüksek değerler $\% 4$ oranında melas ilavesi yapılan silajlarda belirlenmiştir. Üre $x$ melas interaksiyonunda silajların RFV değerleri 61.28 ile 75.29 arasında değişim göstermiş ve en yüksek RFV değeri \%0 üre + \%4 melas uygulamasında belirlenmiştir.

Linn ve Martin (1989), bir yemin RFV değerinin 151 den büyükse o yemin çok üstün kalitede olduğunu, 125 ile 151 arasında ise çok iyi kalitede, 103-124 arasında iyi kalitede, 87-102 arasında orta kalitede, 75-86 arasında ise zayıf ve 75 'in altında ise kötü kalitede olduğunu bildirmişlerdir. Bu sınıflamaya göre çalışmada belirlenen $\% 0$ üre $+\% 4$ melas dışındaki silajların tamamı kötü kaliteli yemler grubuna girmektedir. Yüksel (2019), katkı maddesi kullanılmaksızın yapılan filotu silajlarında RFV değerlerinin 58.24 ile 65.35 arasında değiştiğini bildirmiştir. Bu çalışmada melas katkıları bakımından belirlenen RFV değerleri araştırıcının bildirdiği değerlerden daha yüksek bulunmuştur.

\section{Sonuç ve Öneriler}

Araştırmadan elde edilen sonuçlara göre silajlara üre ilavesi ham protein oranlarının kontrole göre önemli seviyede yükselmesine olanak sağlamıştır. Filotu silajlarının ham protein oranlarının düşük seviyelerde olduğu göz ününe alındığında kaliteli silajların elde edilebilmesi için üre katkısının gerekli olduğunu söylemek mümkündür. Bununla birlikte artan üre katkısı silajlarda fermantasyonu olumsuz etkileyerek $\mathrm{pH}$, fleig puanı, NDF, ADF ve RFV değerlerini olumsuz yönde etkilemiştir. Buna rağmen tüm üre uygulamalarında belirlenen sindirilebilirlik parametreleri kontrole göre daha başarılı bulunmuştur. Melas uygulamaları ise ham protein oranı üzerine bir etki göstermezken silaj fermantasyonunu olumlu yönde etkileyerek $\mathrm{pH}$, fleig puanı, NDF, ADF ve RFV üzerinde olumlu etkilere neden olmuştur. Çalışmadan elde edilen sonuçlar tümüyle değerlendirildiğinde, filotu silajlarında yüksek ham protein oranı ve sindirilebilirlik için silajlara \%1 oranda üre ve \%4 oranda melas ilave edilmesinin yararlı olacağı sonucuna varılmıştır. 
Çıkar Çatışması Beyanı: Makale yazarları aralarında herhangi bir çıkar çatışması olmadığını beyan ederler.

\section{Araştırmacıların Katkı Oranı Beyan Özeti:}

Yazarlar makaleye eşit oranda katkı sağlamış olduklarını beyan ederler.

\&: Bu çalışma Kadir BOLAKAR'ın yüksek lisans tezinden üretilmiştir.

\section{Kaynaklar}

Açıkgöz, E. 2001. Yem Bitkileri. Uludağ Üniversitesi Ziraat Fak. Yay., No: 58, Bursa.

Aguilera, A., Perez-Gil, F., Grande, D., de la Cruz, I. ve Juarez, J. 1997. Digestibility and fermentative characteristics of mango, lemon and corn stover silages with or without addition of molasses and urea. Small Ruminant Research, 26 (1):87-91.

Akyıldız, R. 1986. Yemler Bilgisi ve Teknolojisi. Ankara Üniversitesi Zir. Fak. Yay., 974, Ders Kitabı. 286, Ankara.

Alçiçek, A. ve Özkan, K. 1997. Silo yemlerinde fiziksel ve kimyasal yöntemlerle silaj kalitesinin saptanması. Türkiye I. Silaj Kong., 16-19 Eylül, Bursa, s. 241-246.

Anonim. 2010. Ankom Technicology, Analytical Procedures. Web site, http://www.ankom.com/analyticalprocedures.aspx

Bakıcı, Y. ve Demirel, M. 2004. Determination of qualities of corn, sorghum, sudangrass and sorghum $x$ sudangrass hybrid silages. J. Applied Anim. Res., 26:45-48.

Balabanlı, C., Albayrak, S., Türk, M. ve Yüksel, O. 2010. A research of determination of hay yields and silage qualities of some vetch+cereal mixtures. Turkish Journal of Field Crops. 15(2): 204-208.

Bingöl, T., Bolat, D., Karslı, M.A. ve Akça, İ. 2009. Arpa hasılı ve korunga karışımı silaja farklı düzeylerde melas ilavesinin silaj kalitesi ve sindirilebilirliği üzerine etkileri. Atatürk Üniversitesi Vet. Bil. Derg. 4(1):23-30.

Canbolat, Ö., Kamalak, A. ve Kara, H. 2014. Nar posası silajına (Punica granatum L.) katılan ürenin silaj fermantasyonu, aerobik stabilite ve in vitro gaz üretimi üzerine etkisi. Ankara Üniv Vet Fak Derg, 61:217-223.

Çelik, S., Budas, C., Demirel, M., Bakıcıl, Y. ve Celik, S. 2009. The effects of adding urea and molasses to corn harvested at dough stage on silage fermentation quality, in vitro organic matter digestibility and metabolic energy contents. Journal of Animal and Veterinary Advances, 8(10): 1921-1924.

Demirel, M. ve Yıldız, S. 2001. Süt olum döneminde biçilen arpa hasılına üre ve melas katılmasının silaj kalitesi ve rumende ham besin maddelerinin parçalanabilirliği üzerine etkisi. Yüzüncü Yıl Üni. Zir. Fak. Tar. Bil. Derg., 11(1):55-62.

DLG. 1987. Bewertung von Grünfutter, Silage und Heu. DLG-Merkblatt, 224p.

El Bassam, N. 1998. Energy Plant Species, Their Use and Impact on Environment and Development. James \& James Ltd UK, 321p.

Filya, İ., Sucu, E. ve Hanoğlu, H. 2004. Mısır silajına katılan ürenin silaj fermentasyonu, aerobik stabilite, rumen parçalanabilirliği ve kuzuların besi performansı üzerine etkileri. Tarım Bilimleri Dergisi, 10(3):258-262.

Geren, H., Kavut, Y.T. ve Avcıoğlu, R. 2011. Akdeniz iklim koşullarında filotu (Miscanthus $x$ giganteus)'nun verim ve verim özellikleri ile silolanabilirliği üzerinde bir ön araştırma. Ege Üniv. Ziraat Fak. Derg. 48(3):203-209.

Greef, J.M. ve Deuter, M. 1993. Syntaxonomy of Miscanthus $x$ giganteus, Angewandte Botanik, 67: 87-90.

Güney, M., Demirel, M., Çelik, S., Bakıcı, Y. ve Levendoğlu, T. 2007. Effects of urea, molasses and urea plus molasses suplementation to sorghum silage on the silage quality, in vitro organic matter digestibility and metabolic energy contents. Journal of Biological Sciences, 7 (2): 401-404.

Horrocks, R.D. and Vallentine, J.F. 1999. Harvested Forages. Ac. Press, London, UK.

Kacar, B. ve Ünal, A. 2008. Bitki Analizleri. Nobel Yay., No:1241, Ankara, $892 \mathrm{~s}$.

Kaiser A.L., Piltz, J.W., Burns, H.M. ve Griffiths, N.W. 2004. Successful Silage. Second Edition, Australia, 420p.

Kang, S., Wanapat, M. ve Nunoi, A. 2018. Effect of urea and molasses supplementation on quality of cassava top silage. Journal of Animal and Feed Sci., 27:74-80.

Keskin, B., Yılmaz, İ.H., Karslı, M.A. ve Nursoy, H. 2005. Effects of urea or urea plus molasses supplementation to silages with different sorghum varieties harvested at the milk stage on the quality and in vitro dry matter digestibility of silages. Turk J Vet Anim Sci, 29:1143-1147.

Kılıç, A. 1986. Silo Yemi (Öğretim, Öğrenim ve Uygulama Önerileri). Bilgihan Basımevi, İzmir, $350 \mathrm{~s}$.

Kızılşimşek, M., Günaydın, T., Aslan, A., Keklik, K. ve Açıkgöz, H. 2020. Improving silage feed quality of maize intercropped with some 
legumes. Türk Tarım ve Doğa Bilimleri Dergisi, 7(1): 165-169.

Konca, Y., Büyükkılıç Beyzı, S., Kalıber, M. ve Ülger, i. 2015. chemical and nutritional changes in sunflower silage associated with molasses, lactic acid bacteria and enzyme supplementation. Harran Tar. ve Gıda Bil. Derg., 19(4):223-231.

Lewandowski, I., Clifton-Brown, J.C., Scurlock, J.M.O. ve Huisman, W. 2000. Miscanthus: European experience with a novel energy crop, Biomass and Bioenergy, 19:209-227.

Linn, J. ve Martin, N.P. 1989. Forage Quality Tests and Interpretation. Minnesota Ext. Service. AG-FO-2637. University of Minnesota, Saint Paul.

Mahala, A.G., ve Khalifa I.M. 2007. The effect of molasses levels on quality of sorghum (Sorghum bicolor) silage. Res. J. of Anim. and Vet. Sci., 2:43-46.

Nursoy, H., Deniz, S., Karslı, M.A. ve Kaplan, O. 2002. Erken süt olum döneminde biçilen farklı sorgum hasıllarına üre ve melas katkılarının silaj kalitesi ile in vitro sindirilebilirlik üzerine etkisi. Vet. Bil. Derg. 18(1-2):77-81.

Nursoy, H., Deniz, S., Demirel, M. ve Denek, N. 2003. Süt olum döneminde biçilen kimi mısır hasıllarına üre ve melas katkılarının silaj kalitesi ile sindirilebilir kuru madde verimine etkisi. Turk. J. Vet. Anim. Sci., 27:93-99.

Öztürk, H., 2008. Yenilenebilir Enerji Kaynakları ve Kullanımı. Teknik Yayınevi, Ankara, 367s.

Rong, H., Yu, C., Li, Z., Shimojo M. ve Shao, T. 2013. Evaluation of fermentation dynamics and structural carbohydrate degradation of napiergrass ensiled with additives of urea and molasses. Pak Vet J., 33(3):374-377.

Santos, A.P.M., Santos, E.M., Oliveria, J.S., Ribeiro, O.L., Perazzo, A.F., Pinho, R.M.A., Macedo, A.J.S. ve Pereira, G.A. 2018. Effects of urea addition on the fermentation of sorghum (Sorghum bicolor) silage. Afric. J of Range \& For. Sci., 35(1):55-62.

Siesfers, M.K. ve Bolsen, K.K. 1997. Agronomic and silage quality traits of forage sorghum cultivars in 1995. Türkiye 1 . Silaj Kongresi, 16-19 Eylül, Bursa.

Şakalar, B. ve Kamalak, A. 2016. Melaslı kuru şeker pancarı posasının yonca bitkisinin silolanmasında kullanılması. Anadolu Tarım Bilimleri Der. 31(1)157-164.

Turan, N. ve Seydoşoğlu, S. 2020. Farklı oranlarda karıştırılan yonca, korunga ve italyan çimi hasıllarının silaj ve yem kalitesine etkisinin araştırılması. Türk Tarım ve Doğa Bilimleri Dergisi, 7(3):526-532.
Tümer, S. 2001. Silaj. Ege Tarımsal Araştırma Enst. Müd. Yay., No: 104, İzmir.

Yüksel, O. 2019. Determination of some physical and chemical characterstics of giant miscanthus (Miscanthus x giganteus) silages harvested at different development stages. Fresenius Env. Bulletin, 28(5):4226-4231. 